\title{
Oil and Gas Resources of the Arctic Alaska Petroleum Province
}

\author{
By David W. Houseknecht and Kenneth J. Bird
}

\section{Abstract}

The Arctic Alaska Petroleum Province, encompassing all the lands and adjacent Continental Shelf areas north of the Brooks Range-Herald arch, is one of the most petroleum-productive areas in the United States, having produced about 15 billion bbl of oil. Seven unitized oil fields currently contribute to production, and three additional oil fields have been unitized but are not yet producing. Most known petroleum accumulations involve structural or combination structuralstratigraphic traps related to closure along the Barrow arch, a regional basement high, which has focused regional hydrocarbon migration since Early Cretaceous time. Several oil accumulations in stratigraphic traps have been developed in recent years. In addition to three small gas fields producing for local consumption, more than 20 additional oil and gas discoveries remain undeveloped.

This geologically complex region includes prospective strata within passive-margin, rift, and foreland-basin sequences. Oil and gas were generated from multiple source rocks throughout the region. Although some reservoired oils appear to be derived from a single source rock, evidence for significant mixing of hydrocarbons from multiple source rocks indicates a composite petroleum system. Both extensional and contractional tectonic structures provide ample exploration targets, and recent emphasis on stratigraphic traps has demonstrated a significant resource potential in shelf and turbidite sequences of Jurassic through Tertiary age.

Recent estimates of the total mean volume of undiscovered resources in the Arctic Alaska Petroleum Province by the U.S. Geological Survey and U.S. Minerals Management Service are more than 50 billion bbl of oil and natural-gas liquids and 227 trillion $\mathrm{ft}^{3}$ of gas, distributed approximately equally between Federal offshore and combined onshore and State offshore areas.

\section{Introduction}

The Arctic Alaska Petroleum Province, one of the most petroleum-productive areas in the United States, currently is an exploration target for new additions to reserves. New dis- coveries, along with the economic benefits of applying innovative exploration and production technologies, evolving industry demographics, rising oil and natural-gas prices, and the anticipation that northern Alaska natural-gas resources may become economic and marketable through a planned pipeline, have stimulated a renewed intensity in leasing and exploration activity. Until recently, this activity was focused mostly on State onshore and offshore areas of the central North Slope, as well as the Federal offshore area immediately adjacent to the Federal-State boundary. Exploration in these areas has been mostly for oil in relatively large structural or combination structural-stratigraphic traps similar to that at the Prudhoe Bay field (fig. 1), where approximately 12 billion bbl of oil has been produced and more than 3 billion bbl of reserves remains (table 1; Alaska Division of Oil and Gas, 2006).

Discovery of the 500-million-bbl Alpine oil field in 1994 (fig. 1) on the Colville River delta and success at the nearby Tarn oil field (>100 million bbl recoverable) stimulated interest in exploration for stratigraphic traps. As a result, exploration since 1995 has progressed westward and southward from the main productive fairway into areas where new oil fields in stratigraphic traps may be discovered.

The purpose of this chapter is to provide an overview of known petroleum accumulations in the Arctic Alaska Petroleum Province and to review recent assessments of undiscovered, technically recoverable, conventional petroleum resources. Those resources associated with continuous-type (unconventional) petroleum accumulations, such as lowpermeability basin-centered gas, gas hydrates, and coal-bed methane, are not addressed.

\section{Geologic and Tectonic Setting}

The Arctic Alaska Petroleum Province extends about $1,100 \mathrm{~km}$ from the United States-Canadian border westward to the maritime boundary with Russia, and from 100 to $600 \mathrm{~km}$ northward from the Brooks Range to an arbitrary boundary at the approximate edge of the Continental Shelf (fig. 1; Bird, 2001). Although the edge of the Continental Shelf provides a well-defined physiographic boundary for the province, this edge does not represent a geologic limit to potential petroleum resources. The offshore part of the province is characterized 
by a relatively narrow (100 km wide) shelf in the Beaufort Sea (Scherr and Johnson, 1998) and a broad (600 km wide) shelf in the Chukchi Sea (Sherwood and others, 1998). The province is bounded on the south by the Brooks Range-Herald arch orogenic belt and offshore to the north by the passive continental margin of the Canada Basin (fig. 1).

The principle geologic features of the Arctic Alaska Petroleum Province are summarized in figure 1. The Chukchi and Arctic platforms are remnants of a late Paleozoic through early Mesozoic south-facing (present coordinates) continental margin. These features are separated by the Hanna trough, a north-trending structural sag characterized by extensional normal faulting, in which thick layers of sediment accumulated mostly during the Devonian(?) and Mississippian and into the early Mesozoic. Sherwood and others (1998) considered the Hanna trough to be a failed rift. The Barrow arch and adjacent hingeline fault zone formed during Jurassic to Early Cretaceous rifting. The oceanic Canada Basin and flanking passive margin resulted from this rifting event. At the southern margin of the Arctic and Chukchi platforms and overlapping in time with rifting to the north, an arc-continent collision created the Brooks Range, the adjacent Colville foreland basin, and, presumably, the Herald arch orogenic belt (Moore and others,
1994). Contractional deformation in Tertiary time created the fold-and-thrust belt that extends northward from the Brooks Range and is expressed topographically as the foothills belt (Moore and others, 1994).

\section{Stratigraphy}

Although the stratigraphic record of the Arctic Alaska Petroleum Province extends into the Precambrian, rocks with a potential for petroleum accumulations are dated at Mississippian and younger (fig. 2). The traditional grouping of the rocks into tectonostratigraphic sequences, as proposed by Lerand (1973) and modified by later investigators, emphasizes tectonic history, provenance, and genetic relations. This section briefly describes the tectonostratigraphic sequences north of the Brooks Range.

The Franklinian sequence mostly includes Devonian and older sedimentary rocks representing diverse origins and a complex geologic history. These rocks have been buried and metamorphosed beyond the thermal stage of oil preservation across most of Arctic Alaska, and so they are considered to be economic basement.

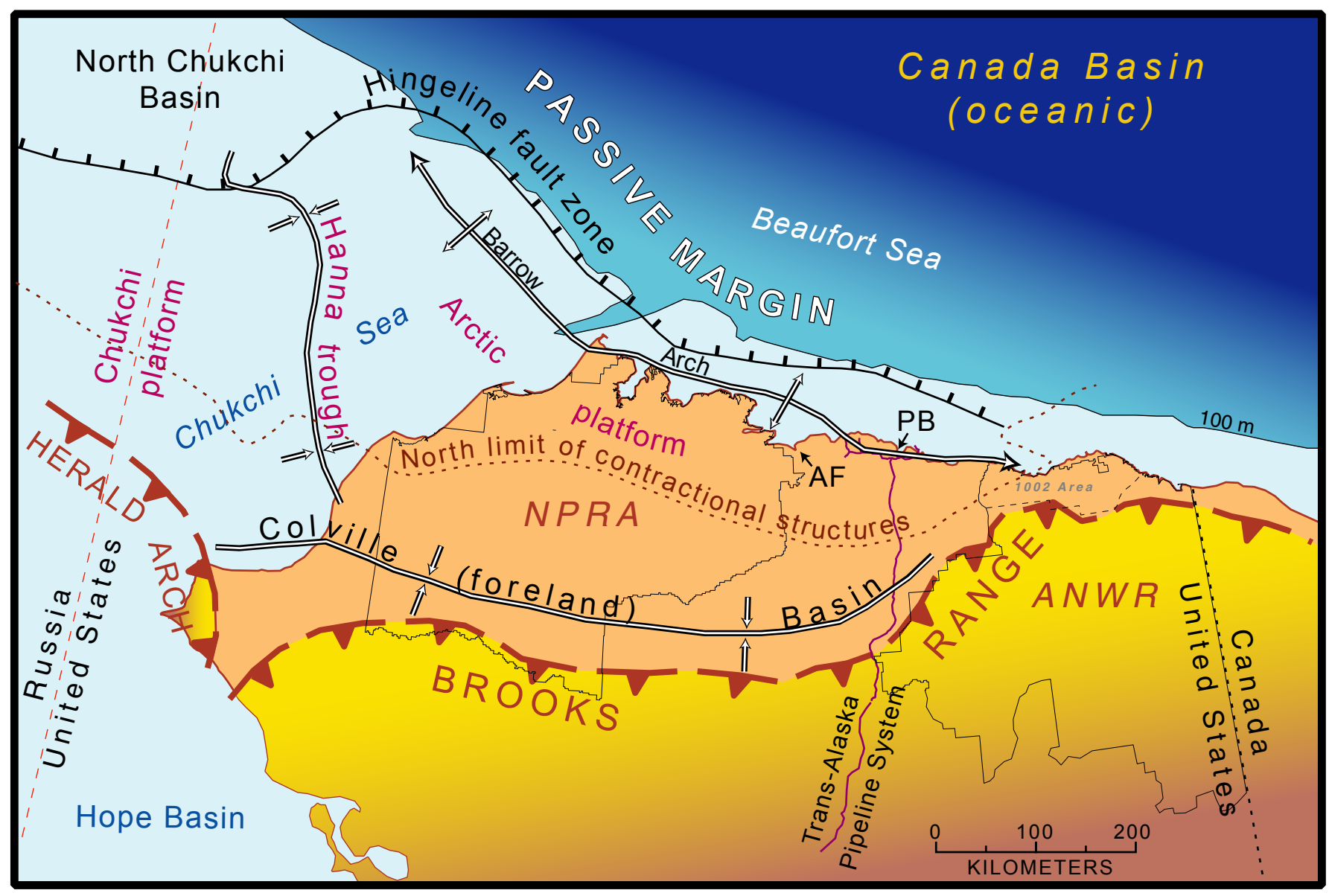

Figure 1. Arctic Alaska Petroleum Province, showing locations of principal geologic features. AF, Alpine oil field; ANWR, Arctic National Wildlife Refuge; NPRA, National Petroleum Reserve in Alaska; PB, Prudhoe Bay oil field. Modified from Bird (2001). 


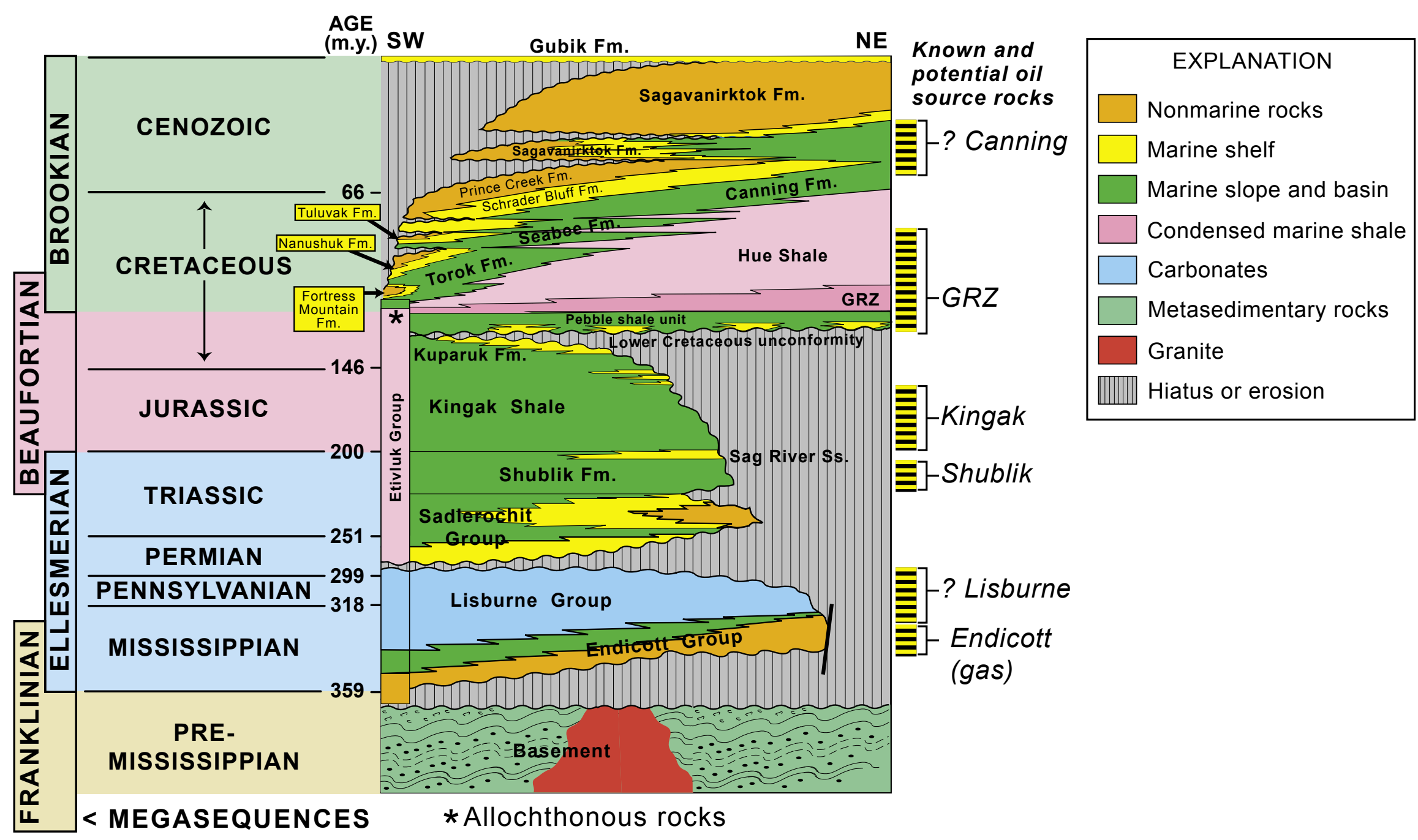

Figure 2. Generalized stratigraphic column for the Arctic Alaska Petroleum Province, emphasizing petroleum-prospective rocks and their tectonostratigraphic subdivisions and reflecting major stages in tectonic development of the region. GRZ, gamma-ray zone of the Hue Shale. 
The Mississippian through Triassic Ellesmerian sequence consists of carbonate and shallow-marine to nonmarine siliciclastic deposits. On the Arctic platform, Ellesmerian strata are continental-shelf deposits that accumulated on a south-facing passive margin. From a northern pinchout or erosional edge near the Barrow arch (fig. 1), they thicken southward to about $2 \mathrm{~km}$ (Moore and others, 1994). Westward, Ellesmerian strata thicken rapidly into the Hanna trough and, beyond, thin onto the Chukchi platform. In the Hanna trough, Devonian(?) and Mississippian rocks are interpreted as synrift deposits, and post-Mississippian strata as thermal sag-phase deposits (Sherwood and others, 1998). Although the Ellesmerian sequence contains both petroleum source and reservoir rocks, source rocks, which lie near the top of the sequence, did not generate petroleum until buried by Beaufortian and Brookian deposits.

The Jurassic and Lower Cretaceous Beaufortian sequence (Hubbard and others, 1987), consisting of synrift deposits derived locally or from the north, is a stratigraphically complex, mud-dominated sequence with multiple unconformities and large variations in thickness (Houseknecht and Bird, 2004) that contains petroleum source and reservoir rocks. Normal faulting and formation of sediment-filled grabens and halfgrabens, some containing more than $3 \mathrm{~km}$ of fill, occur mainly north of the present coastline. Uplift and erosion along the rift margin created a regional Lower Cretaceous unconformity (fig. 2), considered to be the "breakup" unconformity (Grantz and May, 1982). This unconformity, which progressively truncates older rocks northward onto the Barrow arch, is partly responsible for many of the largest oil accumulations in northern Alaska by providing a hydrocarbon-migration pathway for charging multiple, subunconformity reservoirs. Cretaceous mudstone overlying the unconformity serves as a seal, creating combination structural-stratigraphic traps under favorable circumstances, such as at the Prudhoe Bay oil field.

Cretaceous and Tertiary deposits derived from the Brooks Range orogen are assigned to the Brookian sequence.
These voluminous deposits filled the Colville foreland basin, overtopped the rift shoulder (Barrow arch), and built the passive margin that forms the present continental terrace north of Alaska. The Brookian sequence consists of a complex assemblage of siliciclastic strata that include distal, condensed marine mudstone (Hue Shale); relatively deep marine basinal, slope, and outer-shelf mudstone and turbidite sandstone (Torok, Seabee, and Canning Formations); and shallow-marine to coal-bearing nonmarine sandstone, mudstone, and conglomerate (Nanushuk, Tuluvak, Prince Creek, Schrader Bluff, and Sagavanirktok Formations). Organic-rich beds of the Hue Shale are important oil source rocks, and Brookian mudstones may contain gas source rocks. Reservoir rocks consist of turbidite and shallow-marine to nonmarine sandstone, and known oil and gas accumulations occur in both structural and stratigraphic traps within the Brookian sequence. Sediment accumulation in the Colville Basin and on the passive margin north of the Barrow arch generally progressed from west to east during the Cretaceous and Tertiary (Bird and Molenaar, 1992); an exception to this pattern is a significant Tertiary depocenter that was active in the northern Chukchi Sea during the early Tertiary (Sherwood and others, 1998). Deposition of a thick Brookian sequence provided the overburden necessary for thermal maturation of petroleum source rocks in Ellesmerian, Beaufortian, and Brookian strata.

\section{Petroleum Resources}

\section{Known (Discovered) Resources in Unitized Oil Fields}

Approximately 15 billion bbl of oil has been produced from the Arctic Alaska Petroleum Province, and about 12 billion bbl from the Prudhoe Bay oil field (fig. 1; table 1;

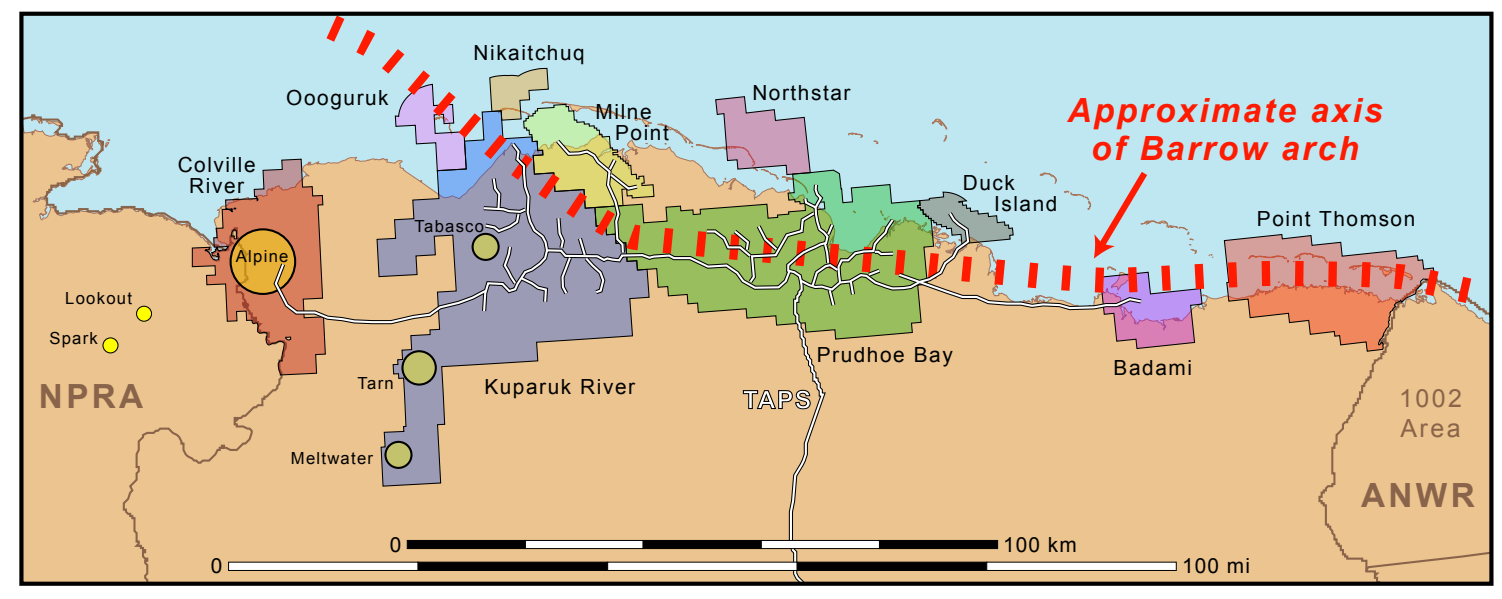

Figure 3. Central Arctic coast of northern Alaska (see fig. 4), showing locations of oil-field units (colored blocks), newly announced satellite pools (Lookout and Spark) to the Colville River unit, Trans-Alaska Pipeline System (TAPS), and boundaries of Federal land (Arctic National Wildlife Refuge [ANWR] and National Petroleum Reserve in Alaska [NPRA]). Data from Alaska Oil and Gas Conservation Commission (2004) and Alaska Division of Oil and Gas (2006). 
Table 1. Cumulative oil production and oil and gas reserves for unitized and other oil fields in northern Alaska and adjacent offshore areas through 2005.

[All values are totals for unitized oil fields. Cumulative oil production includes oil and natural-gas liquids; remaining oil and gas reserves are based on the sum of forecasted production from 2006 through 2035. Reserve estimates include resources in undeveloped accumulations and do not correlate directly with proven reserves reported by field operators. NPRA, National Petroleum Reserve in Alaska]

\begin{tabular}{|c|c|c|c|}
\hline Oil field & $\begin{array}{l}\text { Cumulative } \\
\text { oil production } \\
\text { (million bbl) }\end{array}$ & $\begin{array}{c}\text { Remaining } \\
\text { oil reserves } \\
\text { (million bbl) }\end{array}$ & $\begin{array}{c}\text { Gas reserves } \\
\left(\text { billion } \mathrm{ft}^{3}\right)\end{array}$ \\
\hline Badami $^{1}$ & 4 & 2 & 0 \\
\hline Colville River ${ }^{2}$ & 185 & 510 & 400 \\
\hline Duck Island & 466 & 117 & 843 \\
\hline Kuparuk River ${ }^{3}$ & 2,139 & 1,401 & 1,150 \\
\hline Milne Point & 236 & 391 & 14 \\
\hline Northstar & 90 & 115 & 450 \\
\hline Prudhoe Bay ${ }^{4}$ & 11,990 & 3,192 & 24,526 \\
\hline $\begin{array}{l}\text { Point } \\
\text { Thompson }\end{array}$ & --- & 243 & 8,000 \\
\hline $\begin{array}{l}\text { Other } \\
\text { undeveloped }^{6}\end{array}$ & --- & 488 & --- \\
\hline $\begin{array}{l}\text { NPRA } \\
\text { undeveloped }\end{array}$ & --- & 255 & --- \\
\hline Total & 15,110 & 6,714 & 35,383 \\
\hline
\end{tabular}

${ }^{1}$ Field was put in warm shut-in in August 2003, and production was resumed in 2005 .

${ }^{2}$ Includes the Alpine oil field and its satellites.

${ }^{3}$ Includes the Kuparuk oil field and its satellites.

${ }^{4}$ Includes Prudhoe Bay initial producing areas, Prudhoe Bay satellites, and the "greater Point McIntyre area."

${ }^{5}$ Undeveloped.

${ }^{6}$ Includes the Liberty and other known onshore and offshore accumulations outside NPRA.

Alaska Division of Oil and Gas, 2006). Virtually all production is from an area along the coast near the Barrow arch and centered at Prudhoe Bay (fig. 3). These accumulations are estimated to hold remaining reserves of nearly 7 billion bbl of oil and more than 35 trillion $\mathrm{ft}^{3}$ of gas (table 1; Alaska Division of Oil and Gas, 2006), including resources in undeveloped accumulations that are not typically reported as "proven reserves." Therefore, the reserve estimates reported herein (Alaska Division of Oil and Gas, 2006) are higher than the 4.4 billion bbl and 8.4 trillion $\mathrm{ft}^{3}$ of proven reserves of oil and gas, respectively, reported for the entire State of Alaska by the Energy Information Administration (2006a, b).

Oil (including condensate) is marketed through the TransAlaska Pipeline System (fig. 3); however, gas cannot be marketed at present in the absence of a gas pipeline. Most known petroleum accumulations are in structural and (or) combination structural-stratigraphic traps related to closure along the Barrow arch, which has focused hydrocarbon migration since Early Cretaceous time. Thus, reserves are in multiple stratigraphic horizons in most oil-field units (table 2).

Since 1995, several petroleum accumulations in stratigraphic traps have been developed, including (1) incised shoreface sandstones in the Beaufortian sequence (Alpine pool in the Colville River unit and the newly announced Lookout and Spark discoveries in the National Petroleum Reserve in Alaska [NPRA]); (2) turbidite sandstones in the Brookian sequence (Badami unit; Tarn and Meltwater pools in the Kuparuk River unit; Nanuq pool in the Colville River unit); and (3) fluvial-estuarine incised channel sandstones in the Brookian sequence (Tabasco pool in the Kuparuk River unit, fig. 3; table 2). Although some of these stratigraphic traps occur near the axis of the Barrow arch, most are off structure and thus provide evidence for future potential petroleum discoveries in similar stratigraphic traps.

A large oil, condensate, and natural-gas accumulation occurs in the Point Thomson field, about $80 \mathrm{~km}$ east of Prudhoe Bay (fig. 3 ). Although no production has been reported from this field, the Alaska Division of Oil and Gas (2006) has estimated reserves at 243 million bbl of liquid petroleum and 8 trillion $\mathrm{ft}^{3}$ of gas- the largest known hydrocarbon accumulation in onshore Arctic Alaska that has not yet been developed and produced.

Two new field units, the Oooguruk and Nikaitchuq, were formed in 2003 and 2004, respectively (table 2). Wells in both units have tested positive for oil, and additional delineation drilling is ongoing. One former unit, the Kuukpik, which was located between the Colville River and Oooguruk units (fig. 3), was terminated in 2001 despite positive oil tests from multiple wells (table 2).

\section{Other Known (Discovered) Resources}

At least 27 oil and gas accumulations are known outside the unitized oil fields discussed in the previous subsection (fig. 4; table 2). Three gas accumulations (A-C, fig. 4) have been developed for local use by the community of Barrow near the northernmost part of NPRA. The Alaska Division of Oil and Gas (2006) has estimated that, collectively, these gas fields have produced more than 40 billion $\mathrm{ft}^{3}$ of gas and contain 34 billion $\mathrm{ft}^{3}$ of gas of proven reserves. The remaining 24 known accumulations are undeveloped and include discoveries during the initial exploration within Naval Petroleum Reserve No. 4 (now NPRA) by the U.S. Navy in the 1940s and 1950s, such as the Umiat, Fish Creek, and Simpson oil accumulations and the Gubik, Meade, Square Lake, and Wolf Creek gas accumulations (fig 4; table 2). Among these discoveries, the Umiat ranks as the largest oil accumulation, with an estimated 70 million bbl recoverable (Molenaar, 1982), and the Gubik as the largest gas accumulation, with an estimated 600 billion $\mathrm{ft}^{3}$ recoverable (Kumar and others, 2002). All other petroleum accumulations are either poorly defined or considered to be subeconomic, and so no estimates of recoverable resources 
Table 2. Tectonostratigraphic occurrences of known petroleum accumulations in the Arctic Alaska Petroleum Province.

[Entries are based on stratigraphic position of reservoir. See figure 3 for locations of unitized oil fields, and figure 4 for locations of other developed and undeveloped discoveries. Large Xs, proven reserves or tests that indicate producible hydrocarbons; small xs, possible recoverable resources]

\begin{tabular}{|c|c|c|c|}
\hline Accumulation & Brookian & Beaufortian & Ellesmerian \\
\hline \multicolumn{4}{|c|}{ Active producing units } \\
\hline Badami & $\mathrm{X}$ & -- & -- \\
\hline Colville River & $\mathrm{X}$ & $\mathrm{X}$ & -- \\
\hline Duck Island & -- & -- & $\mathrm{X}$ \\
\hline Kuparuk River & $X$ & $\mathrm{X}$ & -- \\
\hline Milne Point & $\mathrm{X}$ & $\mathrm{X}$ & $X$ \\
\hline Northstar & -- & -- & $\mathrm{X}$ \\
\hline Prudhoe Bay & $\mathrm{X}$ & $\mathrm{X}$ & $\mathrm{X}$ \\
\hline \multicolumn{4}{|c|}{ Former unit terminated in 2001 (no production) } \\
\hline Kuukpik & $\mathrm{x}$ & $\mathrm{X}$ & -- \\
\hline \multicolumn{4}{|c|}{ Units not yet producing } \\
\hline Oooguruk (formed in 2003) & $\mathrm{x}$ & $\mathrm{X}$ & -- \\
\hline Nikaitchuq (formed in 2004) & $\mathrm{x}$ & $\mathrm{X}$ & $\mathrm{X}$ \\
\hline Point Thompson & $\mathrm{X}$ & $\mathrm{x}$ & -- \\
\hline \multicolumn{4}{|c|}{ Other developed discoveries } \\
\hline A. East Barrow—gas (Native lands in NPRA) & -- & $\mathrm{X}$ & -- \\
\hline B. South Barrow—gas (Native lands in NPRA) & -- & $\mathrm{X}$ & -- \\
\hline C. Walakpa-Barrow—gas (Native lands in NPRA) & -- & $\mathrm{X}$ & -- \\
\hline \multicolumn{4}{|c|}{ Other undeveloped discoveries } \\
\hline 1. Burger-gas and condensate (Federal offshore area) & -- & $\mathrm{X}$ & -- \\
\hline 2. East Kurupa—gas (Native lands) & $\mathrm{X}$ & -- & -- \\
\hline 3. East Umiat—gas (Native lands) & $\mathrm{X}$ & -- & -- \\
\hline 4. Fish Creek—oil (NPRA) & $\mathrm{X}$ & -- & -- \\
\hline 5. Gubik—gas (Native lands) & $\mathrm{X}$ & -- & -- \\
\hline 6. Gwydyr Bay—oil (State onshore-offshore areas) & -- & $\mathrm{X}$ & $\mathrm{X}$ \\
\hline 7. Hammerhead—oil (Federal offshore area) & $\mathrm{X}$ & -- & -- \\
\hline 8. Hemi Springs—oil (State onshore area) & -- & $\mathrm{X}$ & -- \\
\hline 9. Kalubik—oil (State offshore area) & $\mathrm{x}$ & $\mathrm{X}$ & -- \\
\hline 10. Kavik_gas (State onshore area) & -- & -- & $\mathrm{X}$ \\
\hline 11. Kemik—gas (State onshore area) & -- & -- & $\mathrm{X}$ \\
\hline 12. Kuvlum—oil (Federal offshore area) & $\mathrm{X}$ & -- & -- \\
\hline 13. Liberty—oil (Federal offshore area) & -- & -- & $\mathrm{X}$ \\
\hline 14. Meade—gas (NPRA) & $\mathrm{X}$ & -- & -- \\
\hline 15. Mikkleson—oil (State onshore-offshore areas) & $\mathrm{X}$ & -- & -- \\
\hline 16. Mooses Tooth—oil (NPRA) & -- & $\mathrm{X}$ & -- \\
\hline 17. Rendezvous—oil (NPRA) & -- & $\mathrm{X}$ & -- \\
\hline 18. Sandpiper — gas and condensate (Federal offshore area) & -- & -- & $\mathrm{X}$ \\
\hline 19. Sikulik—gas (Native lands in NPRA) & -- & $\mathrm{X}$ & -- \\
\hline 20. Simpson—oil (NPRA) & $\mathrm{X}$ & -- & -- \\
\hline 21. Square Lake—gas (NPRA) & $\mathrm{X}$ & -- & -- \\
\hline 22. Stinson—oil (State offshore area) & $\mathrm{X}$ & -- & -- \\
\hline 23. Umiat—oil (NPRA) & $\mathrm{X}$ & -- & -- \\
\hline 24. Wolf Creek—gas (NPRA) & $X$ & -- & -- \\
\hline
\end{tabular}


have been made. The geology of many of these accumulations was summarized by Kumar and others (2002).

Industry exploration of the Brooks Range foothills (fig. 1) during the 1960s and 1970s resulted in the discovery of the East Kurupa, Kavik, and Kemik gas accumulations, all poorly defined in size. Recent estimates suggest recoverable volumes of gas ranging from 95 to 172 billion $\mathrm{ft}^{3}$ in the Kavik accumulation (Verma and others, 2006); no estimates have been made for the other accumulations.

Exploration in Federal and State offshore areas during the 1980 s and 1990s resulted in the discovery of several petroleum accumulations that have not yet been developed. Those accumulations nearest to onshore infrastructure may be the most likely targets. The Liberty (also known as the Tern Island) accumulation, just southeast of the Duck Island unit (figs. 3, 4) and estimated to contain 120 million bbl of recoverable oil, may be developable by extended-reach drilling from onshore (Petroleum News, 2006). Accumulations in both Ellesmerian and Beaufortian reservoirs at Gwydyr Bay are estimated at 48 to 73 million bbl of recoverable oil (Thomas and others, 1993). Other oil discoveries for which no estimates of recoverable resources are available include the Stinson, Hammerhead, and Kuvlum, all north and east of the Point Thomson unit (figs. 3, 4). The Sandpiper accumulation, just northwest of the Northstar unit (figs. 3, 4), contains oil, condensate, and gas; poorly constrained estimates of 93 and 150 million bbl of recoverable oil have been reported (Thomas and others, 1993, 1996).

On the Chukchi Shelf (fig. 4), the Burger gas and condensate accumulation is estimated to contain 9.5 trillion $\mathrm{ft}^{3}$ of gas and 489 million bbl of natural gas liquids (Craig and Sherwood, 2004). These estimates are risked, mean volumes for the "most likely" trap-fill model used in the analysis.

\section{Total Known (Discovered) Resources}

Total known oil and gas resources of the Arctic Alaska Petroleum Province (fig. 1) are estimated and summarized in table 3. Historical production and estimates of remaining reserves are available in the public domain for all producing fields in Arctic Alaska (Alaska Oil and Gas Conservation Commission, 2004; Alaska Division of Oil and Gas, 2006); however, similar data are not available for inplace oil. For this reason, more uncertainty is associated with estimates of inplace oil than with those of ultimate recoverable resources (table 3 ).

The original inplace estimate for reservoirs of the Ellesmerian sequence (fig. 2) in known petroleum accumulations is about 30 billion bbl of oil, of which about 15 billion bbl of oil and 38 trillion $\mathrm{ft}^{3}$ of gas is recoverable. These strata include the main reservoir in the Prudhoe Bay oil field (fig. 1), from which approximately 12 billion bbl of oil has already been produced (Alaska Division of Oil and Gas, 2006). The high recovery factor ( $>50$ percent) reflects the exceptional reservoir quality along the Barrow arch of the main siliciclastic units in the Ellesmerian sequence, including the Kekiktuk Conglomerate, Ivishak Sandstone, and Sag River Sandstone (fig. 2).
Table 3. Estimated volumes of inplace oil and ultimate recoverable oil and gas in known accumulations, listed by tectonostratigraphic reservoir unit.

[From Bird (2001), updated with data from Alaska Oil and Gas Conservation Commission (2004) and Alaska Division of Oil and Gas (2006)]

\begin{tabular}{|c|c|c|c|}
\hline \multirow[b]{2}{*}{ Reservoir } & \multirow{2}{*}{$\begin{array}{l}\text { Estimated } \\
\text { volume of } \\
\text { inplace oil } \\
\text { (billion bbl) }\end{array}$} & \multicolumn{2}{|c|}{ Estimated ultimate recoverable } \\
\hline & & $\begin{array}{c}\text { Oil } \\
\text { (billion bbl) }\end{array}$ & $\begin{array}{c}\text { Gas } \\
\left(\text { trillion } \mathrm{ft}^{3}\right)\end{array}$ \\
\hline Brookian & 40 & 3 & 2 \\
\hline Beaufortian & 10 & 5 & 12 \\
\hline Ellesmerian & 30 & 15 & 38 \\
\hline Total & 80 & 23 & 52 \\
\hline
\end{tabular}

The original inplace estimate for reservoirs of the Beaufortian sequence (fig. 2) in known accumulations is about 10 billion bbl of oil, of which about 5 billion bbl of oil and 12 trillion $\mathrm{ft}^{3}$ of gas is recoverable. These strata include the main reservoirs in the Kuparuk River field, from which approximately 2 billion bbl of oil has already been produced, and the main reservoir in the Colville River unit (Alpine pool and some satellite pools), which is expected to produce more than 500 million bbl of oil. A recovery factor of about 50 percent reflects a combination of good to excellent reservoir quality, the occurrence of light (API gravity, $38-40^{\circ}$ ) oil in several accumulations, and horizontal well-production strategies implemented in recently developed accumulations.

The original inplace estimate for reservoirs of the Brookian sequence (fig. 2) in known accumulations is about 40 billion bbl of oil, of which about 3 billion bbl of oil and 2 trillion $\mathrm{ft}^{3}$ of gas is recoverable. Estimated ultimate recovery for oil includes offshore discoveries (for example, the Hammerhead and Kuvlum) yet to be developed. Brookian reservoirs are generally heterogeneous and, when charged with lighter oil in stratigraphic traps, such as the Tarn (API gravity, $37^{\circ}$ ), recovery factors generally are lower than in Ellesmerian and Beaufortian reservoirs. Estimated ultimate recovery for gas includes accumulations in the Brooks Range foothills (for example, the Gubik) yet to be developed. Huge accumulations of heavy (API gravity, 8-22 ${ }^{\circ}$ ) oil occur in Brookian reservoirs in the Kuparuk River (West Sak and Ugnu pools), Milne Point (Schrader Bluff pool), and Prudhoe Bay (Orion pool) units. In the Kuparuk River field alone, Werner (1987) reported an inplace estimate of 18 to 40 billion bbl for most of these heavy-oil accumulations.

\section{Undiscovered Resources}

The U.S. Geological Survey (USGS) and the U.S. Minerals Management Service (MMS) have recently reassessed undiscovered petroleum resources for most of the Arctic 
Alaska Petroleum Province; the results are summarized in figure 4 and table 4.

Estimated mean volumes of undiscovered oil and gas resources for NPRA (fig. 4), including the adjacent State offshore area and Native holdings within NPRA, are 11.99 billion bbl of total liquid petroleum (crude oil and natural-gas liquids) and 73.03 trillion $\mathrm{ft}^{3}$ of gas (nonassociated and associated) (table 4; Bird and Houseknecht, 2002; Schuenemeyer, 2003). Subsequent to that study, industry has reported data from new discovery wells in the northeastern part of NPRA. The new data from Beaufortian reservoirs indicate that the accumulations contain less oil and more gas and condensate than previously estimated, mostly on the basis of hydrocarbon composition in the Alpine accumulation just east of NPRA (fig. 3). If these new data are representative of undiscovered Beaufortian reservoirs in NPRA, less crude oil and more natural-gas liquids and associated gas may be present (fig. 4; table 4).

USGS-estimated mean volumes of undiscovered oil and gas resources for the central North Slope (fig. 4), located east of NPRA and west of the Arctic National Wildlife Refuge

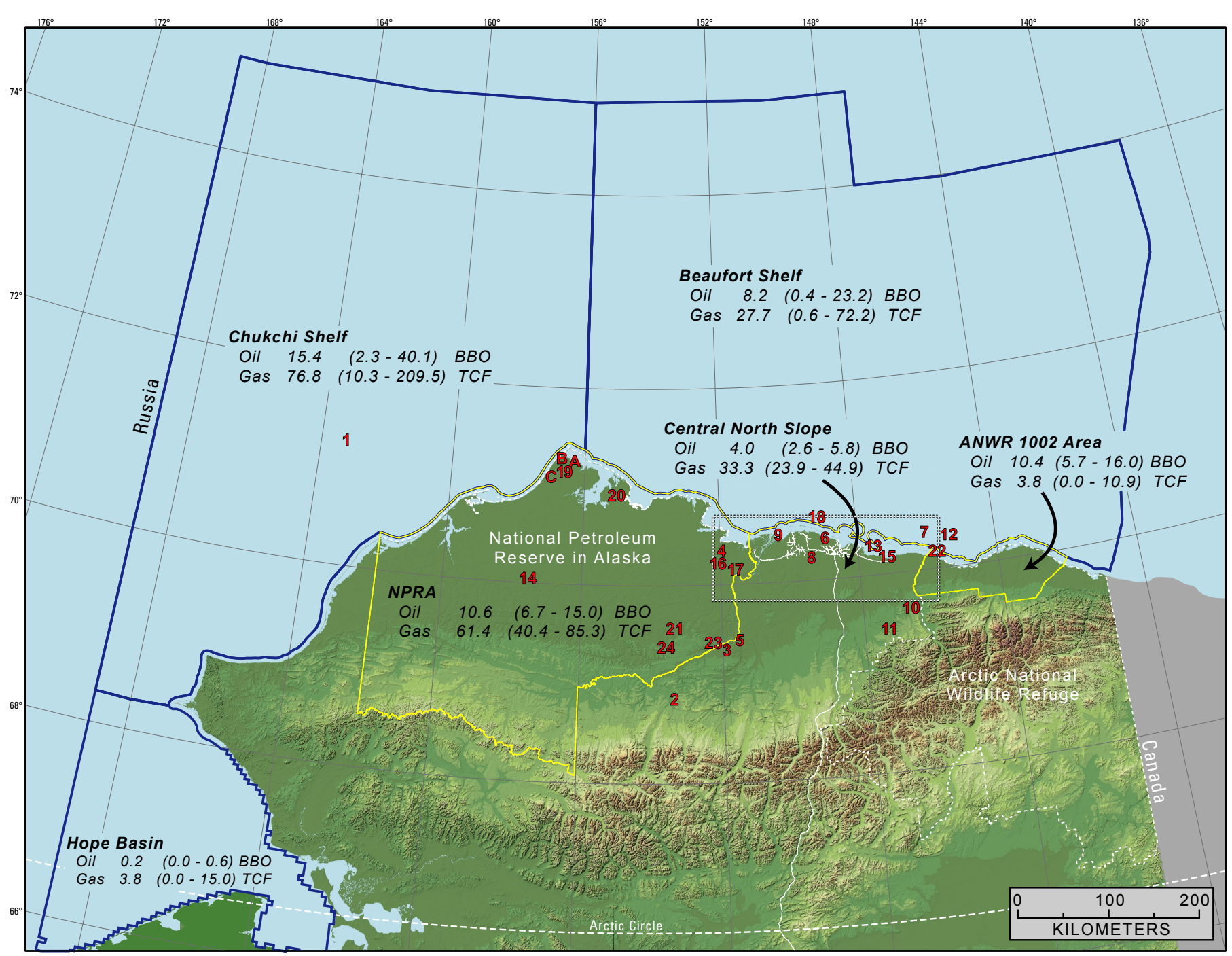

Figure 4. Arctic Alaska Petroleum Province, showing resource estimates (mean and range of 95- to 5-percent-confidence-level volumes) of undiscovered oil (in billions of barrels [BBO]) and gas (in trillions of cubic feet [TCF]) for Federal onshore and offshore assessment areas. Estimates for onshore areas (National Petroleum Reserve in Alaska [NPRA], central North Slope, and 1002 Area of the Arctic National Wildlife Refuge [ANWR]), which include adjacent State offshore area and Native holdings onshore, are from U.S. Geological Survey, where "oil" includes crude oil only and "gas" includes nonassociated gas only. Estimates for Federal offshore area (Hope Basin, Chukchi Shelf, and Beaufort Shelf) are from the U.S. Minerals Management Service, where "oil" includes both crude oil and natural-gas liquids and "gas" includes both nonassociated and associated gas. Red letters and numbers, known (discovered) petroleum accumulations outside unitized oil fields, keyed to table 2. Dashed rectangle, area of figure 3. Data from Schuenemeyer (1999, 2003), Bird and Houseknecht (2001, 2002), Bird and others (2005), and U.S. Minerals Management Service (2006). 
Table 4. Estimated mean volumes of undiscovered, technically recoverable petroleum in conventional accumulations for areas in the Arctic Alaska Petroleum Province.

[Estimates for onshore and State offshore areas versus Federal offshore area are listed separately because of differences in the assessment methods used by the U.S. Geological Survey and U.S. Minerals Management Service. See figure 4 for 95- and 5-percent-confidence-level volumes. ANWR, Arctic National Wildlife Refuge; NPRA, National Petroleum Reserve in Alaska]

\begin{tabular}{|c|c|c|c|c|c|c|}
\hline & \multicolumn{3}{|c|}{$\begin{array}{c}\text { Oil and natural-gas liquids } \\
\text { (billion bbl) }\end{array}$} & \multicolumn{3}{|c|}{$\begin{array}{l}\text { Natural gas } \\
\text { (trillion } \mathrm{ft}^{3} \text { ) }\end{array}$} \\
\hline & $\begin{array}{c}\text { Crude } \\
\text { oil }\end{array}$ & $\begin{array}{c}\text { Natural- } \\
\text { gas } \\
\text { liquids }\end{array}$ & $\begin{array}{l}\text { Total } \\
\text { liquids }\end{array}$ & $\begin{array}{l}\text { Nonassociated } \\
\text { gas }\end{array}$ & $\begin{array}{l}\text { Associated } \\
\text { gas }\end{array}$ & $\begin{array}{l}\text { Total } \\
\text { gas }\end{array}$ \\
\hline \multicolumn{7}{|c|}{ Onshore and State offshore areas } \\
\hline NPRA $^{1}$ & 10.56 & 1.43 & 11.99 & 61.35 & 11.68 & 73.03 \\
\hline Central North Slope ${ }^{2}$ & 3.98 & 0.48 & 4.46 & 33.32 & 4.20 & 37.52 \\
\hline ANWR, 1002 Area $^{3}$ & 10.36 & 0.19 & 10.55 & 3.84 & 4.76 & 8.60 \\
\hline Subtotal & 24.90 & 2.10 & 27.00 & 98.51 & 20.64 & 119.15 \\
\hline \multicolumn{7}{|c|}{ Federal offshore area } \\
\hline Chukchi Shelf ${ }^{4}$ & -- & -- & 15.38 & -- & -- & 76.77 \\
\hline Beaufort Shelf ${ }^{4}$ & -- & -- & 8.22 & -- & -- & 27.65 \\
\hline Hope Basin ${ }^{4}$ & -- & -- & 0.15 & -- & -- & 3.77 \\
\hline Subtotal & -- & -- & 23.75 & -- & -- & 108.19 \\
\hline \multicolumn{7}{|c|}{ Arctic Alaska Petroleum Province onshore and offshore areas } \\
\hline Total & -- & -- & 50.75 & -- & -- & 227.34 \\
\hline
\end{tabular}

${ }^{1}$ Bird and Houseknecht (2002).

${ }^{2}$ Bird and others $(2005$.

${ }^{3}$ Bird and Houseknecht (2001).

${ }^{4}$ U.S. Minerals Management Service (2006).

(ANWR) and including the adjacent State offshore area, are 4.46 billion bbl of total liquid petroleum and 37.52 trillion $\mathrm{ft}^{3}$ of gas (table 4; Bird and others, 2005). USGS-estimated mean volumes of undiscovered oil and gas resources for the 1002 Area of ANWR, including the adjacent State offshore area and Native holdings on the ANWR coastal plain, are 10.55 billion $\mathrm{bbl}$ of total liquid petroleum and 8.60 trillion $\mathrm{ft}^{3}$ of gas (table 4) (Schuenemeyer, 1999; Bird and Houseknecht, 2001).

MMS-estimated mean volumes of undiscovered oil and gas resources for the Federal offshore area (fig. 4) are (1) for the Chukchi Shelf at water depths less than $100 \mathrm{~m}, 15.38$ billion bbl of total liquid petroleum and 76.77 trillion $\mathrm{ft}^{3}$ of gas; (2) for the Beaufort Shelf at water depths less than $500 \mathrm{~m}, 8.22$ billion bbl of total liquid petroleum and 27.65 trillion $\mathrm{ft}^{3}$ of gas; and (3) for the Hope Basin, 0.15 billion bbl of total liquid petroleum and 3.77 trillion $\mathrm{ft}^{3}$ of gas (table 4; U.S. Minerals Management Service, 2006).

The total volumes of undiscovered oil and gas resources in the Arctic Alaska Petroleum Province can be approximated by summing all mean volumes, yielding more than 50 billion bbl of total liquid petroleum and more than 227 trillion $\mathrm{ft}^{3}$ of gas (table 4). Total estimated mean volumes of undiscovered oil and gas resources are approximately equal for both onshore and offshore areas. These total estimated mean volumes lack the ranges of uncertainty inherent in assessments of undiscovered resources. The mean estimates for each assessment area, including oil and gas volumes at the 95- and 5-percentconfidence levels, are listed on figure 4 . Ranges of uncertainty cannot be aggregated to total resources for the entire Arctic Alaska Petroleum Province because of differences in the assessment methods used by the USGS and MMS.

\section{Summary}

Approximately 15 billion bbl of oil has been produced from the Arctic Alaska Petroleum Province, and proven reserves are estimated at more than 7 billion bbl of oil and 35 trillion $\mathrm{ft}^{3}$ of gas. Most oil production is 
from Ellesmerian reservoirs, consisting of Mississippian through Triassic marine carbonate and marine to nonmarine siliciclastic deposits that accumulated on the shelf of a passive continental margin. Lesser production has been from Beaufortian reservoirs, consisting of Jurassic through Early Cretaceous marine siliciclastic deposits associated with the rift opening of the Canada Basin, and from Brookian reservoirs, consisting of Cretaceous through Tertiary marine to nonmarine siliciclastic strata deposited as wedges of sediment shed from the Brooks Range orogenic belt. Most production is from structural and combination structural-stratigraphic traps, although several recent oil discoveries are in purely stratigraphic traps.

Mean estimates of undiscovered, technically recoverable petroleum resources in conventional accumulations for the Arctic Alaska Petroleum Province indicate that more than 50 billion bbl of liquid petroleum (oil and natural-gas liquids) and more than 227 trillion $\mathrm{ft}^{3}$ of gas (nonassociated and associated) remains to be discovered, distributed approximately equally between the Federal offshore area (24 billion bbl of oil and 108 trillion $\mathrm{ft}^{3}$ of gas) and combined onshore and State offshore areas (27 billion bbl of oil and 119 trillion $\mathrm{ft}^{3}$ of gas).

\section{References Cited}

Alaska Division of Oil and Gas, 2006, Alaska oil and gas report, December 2005: URL http://www.dog.dnr.state. ak.us/oil//products/publications/annual/2006_annual_ report/3_HistProj_2006.pdf [accessed Sept. 15, 2006].

Alaska Oil and Gas Conservation Commission, 2004, 2003 annual report: URL http://www.state.ak.us/local/akpages/ ADMIN/ogc/annual/2003/2003annindex.htm [accessed Feb. 10, 2006].

Bird, K.J., 2001, Alaska; a twenty-first-century petroleum province, in Downey, M.W., Threet, J.C., and Morgan, W.A., eds., Petroleum provinces of the twenty-first century: American Association of Petroleum Geologists Memoir 74, p. 137-165.

Bird, K.J., and Houseknecht, D.W., 2001, Arctic National Wildlife Refuge, 1002 Area, petroleum assessment, 1998, including economic analysis: U.S. Geological Survey Fact Sheet 028-01 [URL http://pubs.usgs.gov/fs/fs-0028-01/fs0028-01.pdf].

Bird, K.J., and Houseknecht, D.W., 2002, U.S. Geological Survey 2002 petroleum resource assessment of the National Petroleum Reserve in Alaska (NPRA): U.S. Geological Survey Fact Sheet 045-02 [URL http://pubs.usgs.gov/fs/2002/ fs045-02/fs045-02.pdf].

Bird, K.J., and Molenaar, C.M., 1992, The North Slope foreland basin, Alaska, in Macqueen, R.W., and Leckie, D.A., eds., Foreland basins and fold belts: American Association of Petroleum Geologists Memoir 55, p. 363-393.
Bird, K.J., Houseknecht, D.W., Attanasi, E.D., Moore, T.E., Nelson, P.H., Potter, C.J., Schenk, C.J., Schuenemeyer, J.H., Verma, M.K., Saltus, R.W., Phillips, J.D., Charpentier, R.R., Cook, T.A., Klett, T.R., and Pollastro, R.M, 2005, Oil and gas assessment of central North Slope, Alaska, 2005: U.S. Geological Survey Fact Sheet 2005-3043, 2 p. [URL http:// pubs.usgs.gov/fs/2005/3043/fs2005-3043.pdf].

Craig, J.D., and Sherwood, K.W., 2004, Economic study of the Burger gas discovery, Chukchi shelf, northwest Alaska: U.S. Minerals Management Service, 71 p. [URL http:// www.mms.gov/alaska/re/BurgerResources/Economic\%20 Study\%20of\%20the\%20Burger\%20Gas\%20Discovery.pdf, accessed Mar. 1, 2006].

Energy Information Administration, 2006a, Crude oil proved reserves, reserves changes, and production, Alaska: URL http://tonto.eia.doe.gov/dnav/pet/pet_crd_pres_dcu_SAK_ a.htm [accessed Apr. 5, 2006].

Energy Information Administration, 2006b, Natural gas reserves summary as of Dec. 31, Alaska: URL http:// tonto.eia.doe.gov/dnav/ng/ng_enr_sum_dcu_SAK_a.htm [accessed Apr. 5, 2006].

Grantz, Art, and May, S.D., 1982, Rifting history and structural development of the continental margin north of Alaska, in Watkins, J.S., and Drake, C.L., eds., Studies in continental margin geology: American Association of Petroleum Geologists Memoir 34, p. 77-100.

Houseknecht, D.W., and Bird, K.J., 2004, Sequence stratigraphy of the Kingak Shale (Jurassic-Lower Cretaceous), National Petroleum Reserve in Alaska: American Association of Petroleum Geologists Bulletin, v. 88, no. 3, p. 279-302.

Hubbard, R.J., Edrich, S.P., and Rattey, R.P., 1987, Geologic evolution and hydrocarbon habitat of the "Arctic Alaska Microplate": Marine and Petroleum Geology, v. 4, no. 1, p. 2-34.

Kumar, N., Bird, K.J., Nelson, P.H., Grow, J.A., and Evans, K.R., 2002, A digital atlas of hydrocarbon accumulations within and adjacent to the National Petroleum ReserveAlaska (NPRA): U.S. Geological Survey Open-File Report 02-71, 81 p. [URL http://geopubs.wr.usgs.gov/open-file/ of02-071/].

Lerand, M., 1973, Beaufort Sea, in McCrossan, R.G., ed., The future petroleum provinces of Canada-their geology and potential: Canadian Society of Petroleum Geology Memoir 1, p. 315-386.

Molenaar, C.M., 1982, Umiat field, an oil accumulation in a thrust-faulted anticline, North Slope of Alaska, in Powers, R.B., ed., Geological studies of the Cordilleran thrust belt: Denver, Colo., Rocky Mountain Association of Geologists, v. 2, p. 537-548. 
Moore, T.E., Wallace, W.K., Bird, K.J., Karl, S.M., Mull, C.G., and Dillon, J.T., 1994, Geology of northern Alaska, in Plafker, George, and Berg, H.C., eds., The geology of Alaska, v. G-1 of The geology of North America: Boulder, Colo., Geological Society of America, p. 49-140.

Petroleum News, 2006, BP to sign Liberty MOU with MMS, Corps.: v. 11, no. 6 (Feb. 5, 2006), p. 14.

Scherr, J., and Johnson, P., 1998, Beaufort shelf assessment province, in Sherwood, K.W., ed., Undiscovered oil and gas resources, Alaska Federal offshore: U.S. Minerals Management Service OCS Monograph MMS 98-0054, p. 197-216.

Schuenemeyer, J.H., 1999, Assessment results, in The oil and gas resource potential of the Arctic National Wildlife Refuge 1002 Area, Alaska: U.S. Geological Survey OpenFile Report 98-34, URL http://energy.cr.usgs.gov/OF9834/RS.pdf.

Schuenemeyer, J.H., 2003, Methodology and results from the assessment of oil and gas resources, National Petroleum Reserve, Alaska: U.S. Geological Survey Open-File Report 03-118, URL http://geopubs.wr.usgs.gov/open-file/of03118/of03-118.pdf.

Sherwood, K.W., Craig, J.D., Lothamer, R.T., Johnson, P.P., and Zerwick, S.A., 1998, Chukchi shelf assessment province, in Sherwood, K.W., ed., Undiscovered oil and gas resources, Alaska Federal offshore: U.S. Minerals Management Service OCS Monograph MMS 98-0054, p. 115-196.
Thomas, C.P., Allaire, R.B., Doughty, T.C., Faulder, D.D., Irving, J.S., Jamison, H.C., and White, G.J., 1993, Alaska North Slope national energy strategy initiative-analysis of five undeveloped fields: U.S. Department of Energy report DOE/ID/01570-T164, $350 \mathrm{p}$.

Thomas, C.P., Doughty, T.C., Hackworth, J.H., North, W.B., and Robertson, E.P., 1996, Economics of Alaska North Slope gas utilization options: Butte Falls, Idaho National Engineering Laboratory Report INEL-96/0322, prepared for U.S. Department of Energy, 219 p.

U.S. Minerals Management Service, 2006, Undiscovered oil and gas resources, Alaska federal offshore as of 2006: URL http://www.mms.gov/alaska/re/reports/2006Asmt/Undiscov ered $\% 20$ Oil $\% 20$ and $\% 20$ Gas $\% 20$ Resources $\% 20$ Alaska $\% 20$ 2006.pdf [accessed Mar. 1, 2006].

Verma, M.K., Bird, K.J., Nelson, P.H., and Burruss, R.C., 2006, Reserve potential of the Kavik gas field, North Slope of Alaska [abs.]: American Association of Petroleum Geologists, Pacific Section; Geological Society of America, Cordilleran Section; and Society of Petroleum Engineers, Western Region Joint Meeting Abstracts, p. 71-72.

Werner, M.R., 1987, West Sak and Ugnu sands; low gravity oil zones of the Kuparuk River area, Alaska North Slope, in Tailleur, I., and Weimer, P., eds., Alaskan North Slope geology: Society of Economic Geologists and Mineralogists, Pacific Section, v. 50, p. 109-118. 
Reference citation for this paper:

Houseknecht, D.W., and Bird, K.J., 2006, Oil and gas resources of the Arctic Alaska petroleum province: U.S. Geological Survey Professional Paper 1732-A, 11 p., available online at: http: //pubs.usgs.gov/pp/pp1732a/ 